\title{
Creation of common wheat lines with pyramids of genes for resistance to leaf rust
}

\author{
Davoyan E.R., Bespalova L.A., Agaeva E.V., Davoyan R.O., Khudokormova J.N., \\ Zubanova Yu.S., Mikov D.S., Boldakov D.M. \\ National Center of Grain named after P.P. Lukyanenko, Krasnodar, Russia \\ *email:davayan@rambler.ru
}

The purpose of this work was to transfer to leaf rust (Puccinia triticina Erikss.) resistance genes $\operatorname{Lr} 9, \operatorname{Lr} 19, \operatorname{Lr} 24$, and $\operatorname{Lr} 37$ into common wheat cultivars and the creation of genotypes with the pyramids of these genes using DNA-markers. Isogenic lines of the Tchatcer cultivar were used as donors, and the highly productive cultivars Grom and Tanya, susceptible to leaf rust, were used as recipients. Plants from $F_{1}$ with DNAmarkers linked to the desired $L r$-genes were selected for backcrossing and combining several $L r$-genes in one genotype. Genotypes with combinations of the transmitted genes were identified at each subsequent stage. All plants from $\mathrm{BC}_{3} \mathrm{~F}_{3}$ were evaluated on disease resistance in the field and laboratory conditions and its phenotype, productivity and grain quality traits. Fifty-six lines were obtained with combinations of genes $L r 9+L r 19, L r 9+L r 37, L r 19+L r 24, L r 19+L r 37, L r 24+L r 37$ as a result of the work carried out in $\mathrm{BC}_{3} \mathrm{~F}_{7}$. Seven lines with a combination of genes $\operatorname{Lr} 9+\operatorname{Lr} 19+\operatorname{Lr} 37$ and one with a combination of genes $L r 9+L r 24+L r 37$ were selected. All selected lines were resistant to leaf rust and powdery mildew. In terms of protein and gluten content, most of the lines exceeded those of the standard cultivar Grom. At the same time, many of them were characterized by a significant decrease in productivity in comparison with the recipient cultivars. The most perspective lines were selected for further study in competitive cultivar testing. Line L.17-11Ms35-2 with a combination of genes $L r 9+L r 19$ has a high productivity of $0,9 \mathrm{~kg} / \mathrm{m}^{2}$, good values of protein and gluten content of 15,2 and $27,6 \%$ respectively. Lines L.208-17Ms7, L.208-17Ms8 with a combination of genes $L r 24+L r 37$ have high frost resistance, protein and gluten content at the level of cultivars Grom and Tanya. A semi-dwarf (plant height $82 \mathrm{~cm}$ ) line L.156-16Ms4 with a pyramid of genes $\operatorname{Lr} 9+\operatorname{Lr} 24+\operatorname{Lr} 37$ with high frost resistance and good productivity potential was isolated. 